Western Washington University

Western CEDAR

Fall 1996

\title{
Tiger Teeth Around Their Neck: The Cultural Logic of the Canonization of African American Literature
}

Bill Lyne

Western Washington University, william.lyne@wwu.edu

Follow this and additional works at: https://cedar.wwu.edu/english_facpubs

Part of the American Literature Commons

\section{Recommended Citation}

Lyne, Bill, "Tiger Teeth Around Their Neck: The Cultural Logic of the Canonization of African American Literature" (1996). English Faculty and Staff Publications. 13.

https://cedar.wwu.edu/english_facpubs/13

This Article is brought to you for free and open access by the English at Western CEDAR. It has been accepted for inclusion in English Faculty and Staff Publications by an authorized administrator of Western CEDAR. For more information, please contact westerncedar@wwu.edu. 


\section{Tiger Teeth Around Their Neck: The Cultural Logic of the Canonization} of African American Literature

Power concedes nothing without demand. It never did and it never will. Frederick Douglass, 1857

$\mathrm{M}$ ARX'S REMARK that history always happens twice-the first time as tragedy, the second time as farce-takes an odd twist in the case of the O. J. Simpson trial. The farce of the Simpson proceedings is anticipated by a tragic fiction-Richard Wright's Native Son. O. J. Simpson is certainly a more celebrated native son than Bigger Thomas, but there are many striking congruences. The overdetermined questions swirling around a dead white woman and an accused black man, the spectacular chase scene (Bigger Thomas' chronicled in the newspaper, Simpson's on television), and the carnival trial focused on gruesome evidence and star lawyers are all part of Wright's 1940 novel. The juxtaposition of these two texts is interesting not only for the ways in which the details of the fiction predict the Simpson saga, but also for the way in which it highlights how our institutions of representation circumscribe the ways we talk about African American politics and culture.

Johnny Cochran and the rest of Simpson's legal "dream team" did not choose to portray their client as an American native son. Faced with 
evidence that was arguably more extensive and more compelling than the evidence the state's attorney could offer against Bigger Thomas, Simpson's lawyers could have deployed the same sort of socioeconomic analysis used by Bigger's lawyer, Boris Max. Where Max talked about the capitalist forces that converged on the south side of Chicago to create Bigger, Cochran could have told the jury about Simpson's childhood in a San Francisco ghetto, the misogynist culture of American collegiate and professional sports, and the attitude fostered by the authorities' willingness to ignore spousal abuse in general and Simpson's wife-beating in particular. Among the many reasons not to deploy such a strategy, one of the best would surely be that it did not work for Bigger Thomas. Not only did Boris Max's Marxist analysis not lead to Bigger's acquittal, it did not even keep him off death row.

But while Cochran chose not to discuss the larger forces that may have shaped O. J. Simpson, he did not completely abandon social and institutional analysis. His plea for the jury to "send a message" invoked a history of criminal justice oppression and police force brutality that stretched well beyond the boundaries of the People vs. O. J. Simpson. Despite the fact of a racially mixed jury, most commentators on the case (including one of Simpson's own attorneys, Robert Shapiro) read Cochran's remarks in black and white, as a simple matter of "playing the race card." This reading was reinforced with continual reference to polls that showed blacks and whites deeply divided on the question of Simpson's guilt, and with the constant video replay of crowds of black people cheering the verdict juxtaposed with crowds of white people looking dismayed and angry. No one in the mainstream media suggested that the white and Hispanic working-class members of the jury may have empathized with Cochran's indictment of power and police on grounds other than race. This argument would not have sold commercial time, not just because it does not fit comfortably into a sound bite, but also because we have no context, even in those spaces less frenzied than television and the mainstream media, to hear such an argument.

This is perhaps the most important point of comparison between the O. J. Simpson trial and Native Son. The reception of these two texts takes place in a matrix of readings and interpretations that shapes what we hear and how we hear it. As Eric Cheyfitz points out, "The books we read in school and the way we learn to read them socialize us" (541, my italics). The canonization of Native Son makes it at least part of the mix 
that creates the forms and simulacra that frame discussions of race in the United States. And the terms of its canonization, "the way we learn to read" Native Son, reveals a lot about the way we tend to read the Simpson trial.

Native Son is the sore thumb among the handful of original African American crossover hits. Frederick Douglass' I 845 Narrative, W.E.B. Du Bois' The Souls of Black Folk, Ralph Ellison's Invisible Man, and James Baldwin's Go Tell It On the Mountain all achieved canonical status on the basis of their appeal to white aesthetics. The critical establishment acknowledged that these men wrote with the universalized grace and beauty derived from the Emerson-to-Fitzgerald great tradition and thus deserved a place in the canon and the classroom. In general, African American texts crossed into the canon because critics described them the way that Jonathan Baumbach described Invisible Man in 1965 :

I hesitate to call Ralph Ellison's Invisible Man a Negro novel, though of course it is written by a Negro and is centrally concerned with the experiences of a Negro.... Despite the differences in their external concerns, Ellison has more in common as a novelist with Joyce, Melville, Camus, Kafka, West, and Faulkner than he does with other serious Negro writers like James Baldwin and Richard Wright. To concentrate on the idiom of a serious novel, no matter how distinctive its peculiarities, is to depreciate it, to minimize the universality of its implications. Though the protagonist of Invisible Man is a southern Negro, he is, in Ellison's rendering, profoundly all of us. (73)'

Native Son, written by one of those "other serious Negro writers," has become one of our most canonized African American texts, and yet has been described by everyone from James Baldwin to Harold Bloom as lacking in "universal" implications and as an aesthetic failure. Referring to Wright's "bad authorial ear," and his inability to "rise always even to Dreiser's customarily bad level of writing," Bloom writes,

It is rather too late to make so apparently irrelevant an observation, since Wright has become a canonical author, for wholesome societal purposes with which I am happy to concur. (2) 
Those wholesome societal purposes for which Bloom is willing to suspend the usual aesthetic criteria include "the claims of history, society, political economy, and the longer records of oppression and injustice that history continues to scant" (2). This is the familiar reading of Native Son as "protest literature" from that part of the canon where we keep the books we read because they are good for us, not because they taste good.

But even those books we canonize in order to improve our society are made to fit comfortable categories. Canonization, even for wholesome societal purposes, tells certain stories about the canonized text while eliding others. Bigger Thomas' lawyer has not taken the same kind of media beating as $\mathrm{O}$. J. Simpson's dream team, but his strategy has not fared very well in canonical literary criticism. One of American literature's most overt and damning critiques of Western capitalism and racism is Boris Max's sixteen-page speech to the judge at the end of $\mathrm{Na}$ tive Son. This description of the economic forces that created both the South Side of Chicago and Bigger Thomas (later elaborated by Wright himself in "How Bigger Was Born") is also one of the most reviled passages in the canon. Even the book's staunchest and most didactic advocates see the ending as hopelessly flawed. Dan McCall, in The Example of Richard Wright, describes Wright as having "falsified the message of [Bigger Thomas]" (90). Robert A. Bone tells us that "Wright has allowed his statement as a Communist to overwhelm his statement as an artist" (23). And Irving Howe, in his famously laudatory "Black Boys and Native Sons," writes that, "The long speech by Bigger's radical lawyer Max ... is ill-related to the book itself" (IO4).

Native Son is a book that even an admirer like Howe calls crude, melodramatic, and claustrophobic. It is curious, then, that Max's speech should be singled out for such a unanimous and damning critique. Why, if the entire novel is artistically suspect and its canonization depends mostly on its social effects, should we be so particularly concerned to point out the ineptitude of this one passage? Max's speech is not, by a long stretch, the most gruesome scene in Native Son, nor is it, arguably, the place where Wright's "bad authorial ear" is most on display.

But it is the passage most likely to circumvent aesthetic catharsis and raise readers' questions about social institutions-those that segregate our cities, those that create and enforce economic oppression, and, by extension, those institutions that create and enforce canons. When 
Max identifies Mr. Dalton as a slumlord, and speaks of "a problem whose reality sprawls over a third of this nation" $(361)$, and points to the "leaders and their pet vassals" whose "lives are built upon a historical deed of wrong against many people, people from whose lives they have bled their leisure and their luxury" (357), he insists that the reader of Native Son recognize the institutional forces that will continue to create the circumstances where Bigger Thomases will continue to kill Mary Daltons long after Bigger has been put to death. And by putting the speech in the mouth of a "flat" character like Max and making it the only part of the book not told from Bigger Thomas' point of view, Wright removes any opportunity to interpret it in terms of individual pathology. Thus, the critical objections to this speech become a crucial part of the process of canonizing Native Son.

Canon-making critics like McCall, Bone, and Howe see Bigger Thomas as a "Black Boy" (Howe) or "the bad nigger" (McCall), whose representation exposes American racism. But by eliminating Max's speech, these critics cut this analysis of racism loose from the Marxist moorings that Wright gave it. Ironically, the part of Native Son that moves beyond race-bound narrative and toward something more "universal" (a critique of capitalism that strikes at the heart of American history) is the part that even leftist critics like Howe want to leave out. Even Paul N. Siegel's "The Conclusion of Richard Wright's Native Son," which attempts to reclaim the ending of the novel, does so by insisting that "Max is not a Communist party member" and that the speech is not "a savage attack on capitalism or a statement of a 'guilt of the nation thesis'" ( 108,109 ). Siegel goes on to tell us that the speech "is not an obtrusion" because it brings together a "number of recurring themes and images in the novel" ( 1 I 0 ). These "themes and images" include such tried and true "universals" as blindness, walls, and freedom.

The critical establishment's choice either to banish this section of Native Son or to see it only in carefully circumscribed thematic terms echoes Ernest Hemingway's admonition that we should stop reading Huckleberry Finn "where the Nigger Jim is stolen from the boys. That is the real end. The rest is just cheating" (22). As Ralph Ellison points out in "Twentieth-Century Fiction and the Black Mask of Humanity," Hemingway "speaks as a victim of that culture of which he himself is so critical." Just as what Ellison calls "Hemingway's blindness to the moral values of Huckleberry Finn" is masked behind "his sensitivity to its tech- 
nical aspects" (34-35), so is our canon-builders' distaste for the imperatives of Max's speech hidden behind concern over the mixing of aesthetics and ideology.

Canonizing Native Son without its ending lets it fit easily into a way of reading that Hazel Carby describes as "obsessed with the construction of identities rather than relations of power and domination" that "in practice, concentrates on the effect ... on a (white) norm" (193). This sort of reading allows our canon to become blacker or more "multicultural" while maintaining the stable, naturalized poles of identity and difference between which a text like Native Son must fit.

Young black men from Eldridge Cleaver to Clarence Thomas have seen themselves and their anger in Bigger Thomas. Cleaver discovers Native Son in a prison library and his experience is echoed twenty-six years later by Washington Post reporter Nathan McCall in Makes Me Wanna Holler:

I identified strongly with Bigger and the book's narrative. He was twenty, the same age as me. He felt the things I felt, and, like me, he wound up in prison. The book's portrait of Bigger captured all those conflicting feelings-restless anger, hopelessness, a tough facade among blacks and a deep-seated fear of whites-that I'd sensed in myself but was unable to express. Often, during my teenage years, I'd felt like Biggerheaded down a road toward a destruction I couldn't ward off, beaten by forces so large and amorphous that I had no idea how to fight back. I was surprised that somebody had written a book that so closely reflected my experiences and feelings. (157)

Native Son has become such a staple in young black men's prison memoirs that Jill Nelson, reviewing Makes Me Wanna Holler for The Nation, is able to write,

In an almost obligatory rendering of the prison experience, McCall goes to jail ... reads Native Son, decides to become a journalist and is paroled after three years, determined to turn his life around. (564)

Wright's novel has become a touchstone for the anger of young African American men. Reading it in the prescribed way focuses their anger 
away from its source and toward an identification with Bigger Thomas. For McCall, the "large and amorphous" forces become secondary to the pleasure of discovering someone who feels the same way that he does and winds up in a similar jail cell. Political and social experiences become personal problems, and reading Native Son becomes an early part of the twelve-step program that lets young black men transcend their problem and trade their Bigger Thomas demons for the more acceptable identities of Washington Post reporters and Supreme Court justices.

Next to this black male tradition of grappling with the Bigger Thomas identity, it becomes relatively easy to read Native Son in terms of difference. In "How Bigger Was Born," Wright laments the "awfully naive mistake" of his first book, Uncle Tom's Children: "I found that I had written a book which even bankers' daughters could read and weep over and feel good about." Wanting to deny his readers the escape hatch of pathos, Wright vows to write a book "so hard and deep" that no one could possibly mistake "what had made [Bigger] and what he meant" (xxvii). But the canonization of Native Son has gone a long way toward undercutting this intention. Wright may have set out to challenge his readers' "deepest held notions and convictions," but once his book has been stripped of its ending all he has succeeded in doing is trading the moments of identity that he created in Uncle Tom's Children for the difference of Bigger Thomas. As long as we can ignore Max's explanation of what made Bigger, we can read Native Son as the dark underbelly of Huckleberry Finn without its ending-simply the story of a troubled youth. Wright may very well have succeeded in frightening bankers' daughters, but this fear now functions simply to make our students feel diverse.

The way that this method of canonization creates a narrowed framework for reading carries over to our larger narratives about race. The identity-difference paradigm serves to simplify complex issues and derail coherent political discourse. Richard Wright's "vulgar Marxism" plays out the second time as vulgar liberalism. By the time he was arrested and charged with his ex-wife's murder, O. J. Simpson had long since crossed several sets of tracks. But as soon as he re-enters the $\mathrm{Na}$ tive Son narrative, our reading reverts to identity and difference, with about two-thirds of black Americans polled recognizing Simpson as always innocent, while a similar number of white Americans see him as already guilty. 
It's no accident that people like Malcolm X and Martin Luther King were destroyed at those moments of their political careers when ... they replace nationalism with a critique of imperialism.

bell hooks

Though our canon machinery encourages either/or thinking, our institutionally sanctioned discourse derides it. On February 22, 1995, Amiri Baraka addressed an audience in Tacoma, Washington, and, after dividing the world into people who own things and people who don't, demanded that his listeners declare "whose side you're going to be on." In order to be on the "right" side, he told his mostly middleclass listeners, "you must commit class suicide." This is the sort of stark and uncompromising thetoric that has relegated Baraka to the oldies nostalgia circuit. Along with writers and critics such as Larry Neal, Don L. Lee, Addison Gayle, and Stephen Henderson, we think of a dashikiclad Baraka as one of the exemplary figures of the Black Arts/Black Aesthetic movement, whose "polemics and excesses are what we often remember" (Smith I08). Black Arts is the aesthetic counterpart of the politics of Black Power and both movements are popularly associated not with the kind of class analysis that Baraka offered in Tacoma, but with a strident cultural nationalism that has become a familiar stalking horse in discussions of African American politics. When middle-brow publications like The New Yorker and The Atlantic Monthly devote long articles to the salutary emergence of black academic "public intellectuals" like Cornel West, Michael Eric Dyson, and Henry Louis Gates, Jr., they are always very careful to point out that these thinkers have moved beyond their sixties predecessors' "narrow" nationalism and toward a more nuanced, integrationist and integratable blackness. Writing about "The New Intellectuals" for The Atlantic, Robert S. Boynton tells us that these intellectuals arrived "on campus as the influence of the radical Black Panthers was cresting," and that "by the time they were old enough to engage the Black Power movement themselves, the arguments were beginning to sound a little old" $\left(6_{4}\right)$.

There are a couple of important subtexts to the way that this black intellectual history has been written in academic criticism and the popular press. The first is that "either/or" radicals like Baraka had a large 
hand in creating the institutional space now occupied by the African American professoriat.' The African American studies programs that today are firmly institutionalized in America's elite universities are a direct result of the political energy generated by the Black Arts and Black Power movements. The Du Bois Institute at Harvard that now houses Henry Louis Gates, Jr., and Cornel West is the legacy of student protests inspired by the "nation time" rhetoric of people like Baraka and Stokely Carmichael.

The second interesting subtext to the last twenty-five years of black intellectual history is the fate of black cultural nationalism itself. In Blues, Ideology, and Afro-American Literature, Houston A. Baker, Jr., describes "the philosophical orientation of the Black Aesthetic as romantic Marxism" (8I, my italics). The romantic half of this formulation is the space of separatist nationalism. Referring to Stephen Henderson's anthology Understanding the New Black Poetry, Baker writes about the "assumption that 'Blackness' is not a theoretical reification, but a reality accessible only to those who can 'imagine' in uniquely black ways" (8r). This "mysterious trait of consciousness" (summed up in the contemporary T-shirt slogan, "It's a black thing") persists in the current intellectual dialogue. Boynton may describe cultural nationalism as little more than a foil for "second generation" black intellectuals, but the actual work of these writers tells a different story. Gates' criticism shows a complex call and response relationship with the Black Aesthetic. Both Dyson and West find inspiration and nourishment in the image and ideas of Malcolm X. Baker has never completely abandoned the Black Aesthetic and his deep engagement with rap music is necessarily in dialogue with cultural nationalism. All of these critics may have moved beyond Black Power, but that movement has never been a simple repudiation. And, while scholars like Gates and West receive most of the television and bestseller attention, there is still a place in academia (though admittedly not in the Ivy League) for unrepentant Afro-centrists like Leonard Jefferies and Molefi Asante.

While the romanticism of the Black Aesthetic has endured, the Marxist half of Baker's paradigm has not fared so well. Like Native Son, the Black Arts movement survives in our institutional imagination without its economic determinism. The "revolutionary" and didactic poems of sixties and seventies Black Arts writers have been largely forgotten. Prescriptive injunctions like Ron Karenga's that "black art ... 
must be functional, collective and committing" (33) now seem as dated and unconvincing as the tenets of Soviet socialist realism or the artistic strictures of Mao Ze-dong. Critics as diverse as Larry Neal and Gates have contributed decisively to the hegemonic assumptions about the limitations of "race and superstructure" criticism.

This split between the way Black Aesthetic romanticism is received, tolerated, and engaged, and the way that Black Aesthetic Marxism is silenced and rejected has an interesting parallel in the larger politics of Black Power. At least since the nineteenth century, Black nationalist essentialism has had a fairly secure and enduring voice in American racial politics. The Nation of Islam, the most prominent nationalist group of the I96os, remains vital today, with a leader (Louis Farrakhan) who is very visible in the mainstream media. Hollywood millions finance the celluloid representation of Malcolm X talking about "white devils." And the nationalist sounds of rap music pervade mainstream airwaves. Quite often this sort of expression is demonized and dismissed as "reverse racism," "militant," or "terrorist," but even when it appears on the landscape as nothing more than the necessary evil other, it still appears.

Black economic critique, on the other hand, is almost always actively suppressed. The Black Panthers, whose economic philosophy was avowedly Marxist, were declared by J. Edgar Hoover to be the single greatest threat to American domestic tranquillity, and were, more than any other 1960 sesistance movement, systematically assassinated by local and federal police. As the young black male energy associated with the Panthers has been channeled away from political reform and toward the more capitalist "crypto-Keynesian youth employment program operated by the cocaine cartels," police response has moved away from extermination and toward acceptable containment (Davis 309). As Sonia Sanchez put it, "The drug-taking, apathetic young Black people we bemoan today are the result of our failure to protect and cherish the Black Panthers during the Sixties" (qtd. in Davis 293).4 Malcolm X was assassinated with at least the tacit compliance of the FBI not long after his critique shifted away from the religious fundamentalism of Elijah Muhammad and toward a more internationally grounded program of economic empowerment. ${ }^{5}$ Martin Luther King, Jr.'s, death (and the shady circumstances surrounding it) came on the eve of the poor people's march on Washington and shortly after he had begun to engage 
America less in terms of civil rights and more in terms of economic reform. ${ }^{6}$ Both of these figures are iconically celebrated today, but it is very rare that our celebrations, holidays, and movies take note of their late turns toward radical economic critique. This same dynamic continues in virtually all of the contemporary places where power takes note of black dissent. Our institutions and debates have no place for the voices that see racial injustice as a symptom or corollary of destructive capitalism.

Patricia Williams, in her book The Alchemy of Race and Rights, describes the two ways we do hear black expression:

For blacks, describing needs has been a dismal failure as political activity. It has succeeded only as a literary achievement. The history of our need is certainly moving enough to have been called poetry, oratory, epic entertainment-but it has never been treated by white institutions as the statement of a political priority. (I don't mean to undervalue the liberating power for blacks of such poetry, oratory, and epic; my concern is the degree to which it has been compartmentalized by the larger culture as something other than political expression.) Some of our greatest politicians have been forced to become ministers or blues singers. Even white descriptions of "the blues" tend to remove the daily hunger and hurt from need and abstract it into a mood. And whoever would legislate against depression? Particularly something as rich, soulful, and sonorously productive as black expression. . . But from blacks, stark statistical statements of need are heard as strident, discordant, and unharmonious. Heard not as political but only against the backdrop of their erstwhile musicality, they are again abstracted to mood and angry sounds. (15I-52)

Williams' description of the way black expression is heard easily fits an "either/or" model_-either something bluesy or soulful or something discordant and angry. (A paradigmatic instance of this dichotomy is the sixties' mainstream media representation of Martin Luther King, Jr., as the harmonious, acceptable black spokesman versus Malcolm X as the angry, unintelligible terrorist.) This model's description of binary black voices also points toward the way some positions are not heard. Ralph Ellison is heard as soulful blues, Bigger Thomas is heard as "mood and angry sounds," and the Marxist vision of Richard Wright is silenced. 
Martin Luther King's Christian nonviolence is blues, Malcolm X's Muslim separatist nationalism is angry, the Black Panthers' Marxism is silenced. Black cultural nationalism becomes the necessary, easily demonized and contained Other that gives the illusion of oppositional space, while Black dissent that moves away from race and toward class and economics is excluded from the conversation.

As long as it was a bourgeois nationalist, reactionary nationalist kind of trend-a "hate whitey" kind of thing, during that period of the movement, they didn't really have any problem with that. They might get offcially excited. ...

That is, if you say that the enemy is "all whites" without making a class analysis and showing that there's only a handful of super-billionaire vampires that actually control the society, the ruling class. When you do that and start making an analysis with your art in a forceful way, then they don't see that as a charming commodity that they need like they might need some tiger teeth around their neck.

Amiri Baraka, $x 984$

This circumscribed conversation is replicated in the way we have canonized African American literature. The catalytic Black Power energy that created a permanent place in English departments for African American literature has been turned back to the point where the critical dynamic surrounding Native Son has become the hegemonic paradigm for canonizing African American texts. Our literary canon has become more "diverse" with the addition of numerous black voices, but a strong tradition of radical left criticism remains excluded.

Paul Lauter, the general editor of The Heath Anthology of American Literature and an important historian and critic of curricular revision, cites Stokely Carmichael's 1966 "Black Power" speech as one of the touchstones of canon reform. Juxtaposing Carmichael and the American debut of Jacques Derrida at the Johns Hopkins Humanities Center (also in 1966), Lauter distinguishes between what he calls "ludic" and "canonical" criticism. The ludic is the "deconstructive, speculative, formalist" method of analysis "that has become increasingly central to the practice of literary study" (Canons 133). Canonical criticism, which Lauter sees as the more valuable, is "a part of a broader effort to recon- 
struct our society, and particularly our educational institutions, on a more democratic and equitable basis" (144-45). The argument for replacing a formalist impulse with a more activist one that "places the work and life of women and minority men into the curriculum" (145) permeates Lauter's collection of essays, Canons and Contexts, as well as the Reconstructing American Literature project and the Heath Anthology.

Lauter's invocation of Carmichael is interesting in this context, as Carmichael's position is an excellent example of the kind that has been excluded from mainstream either/or cultural discourse. Black Power: The Politics of Liberation in America, the 1967 manifesto that Carmichael wrote with Charles V. Hamilton, falls squarely on the Marxist side of Black Power as "romantic Marxism." Presenting itself as "a political framework and ideology which represents the last reasonable opportunity for this society to work out its racial problems," Black Power argues forcefully for African American political and economic empowerment as a crucial element in the "development of a viable larger society" (vii). Rather than invoke the black nationalist "white devil," Carmichael and Hamilton critique the colonialism of the "white power structure" (7) and discuss the viability of African American political and economic strategies from Mississippi to Detroit. They end by calling

at this time for new political forms which will be the link between broadened participation (now occurring) and legitimate government. These forms will provide a means whereby a newly politicized people can get what they need from the government. It is not enough to add more and more people to the voter rolls and then send them into the old "do-nothing" compromise-oriented political parties. Those new voters will only become frustrated and alienated. It is no good to enact an antipoverty program calling for "maximum feasible participation of the poor" and then saddle that program with old City Hall and bureaucratic restrictions. The people will see this only as a perpetuation of the same old colonial situation. ( $181-82$ )

In trying to claim for The Heath Anthology the cultural and institutional space created by the Black Power movement, Lauter rewrites Carmichael's "new political forms" in terms of the romance of identity politics. Suggesting that "we strip away from Carmichael's exposition of 
'black power' some of its rhetorical vehemence," Lauter dilutes Carmichael's call to "smash everything Western civilization has created" to an effort to reclaim Black identity for the "Western civilization courses" that have excluded it. He goes on to invoke critics such as Stephen Henderson, Addison Gayle, and Houston Baker and the "central concern" that they "share with Carmichael: to define what it means to be black in late twentieth-century America" (Canons I45-46). This move to replace the politics of Black Power with Black identity allows Lauter and his fellow editors of The Heath Anthology to adopt a reform stance without disrupting the usual canonization processes.

The canonization of African American or other "minority" literatures is an integrationist project, as Lauter declares that "the progress of canonical criticism cannot be understood separately from the personnel practices designated as 'affirmative action'” (145). And just as employment affirmative action tends to do the most for those already in the middle class, curricular affirmative action does for our canons what The Cosby Show or The Fresh Prince of Bel Air does for our airwaves, making the picture a bit darker without really disrupting the stories we usually tell. Suppose, for example, that in a survey of American literature course we wanted to trace a particular genealogy of African American male discourse and we chose to do that by looking at Frederick Douglass, W.E.B. Du Bois, James Baldwin, and Amiri Baraka. Using almost any standard, we could probably consider these figures "major" and appropriate to such an inquiry. But if we chose to use the selections offered in The Heath, or almost any other anthology of American literature, the story would be all too familiar and the silences both predictable and deafening.

Frederick Douglass is represented in The Heath, as well as The Norton Anthology of American Literature, The Harper American Literature, and McGraw-Hill's The American Tradition in Literature with his 1845 Narrative of the Life of Frederick Douglass, an American Slave, Written by Himself. The Heath and The Norton both also include "What to the Slave is the Fourth of July?" Harper's anthology supplements the I 845 Narrative with "Letter to Thomas Auld" (written to Douglass' former master), "At Home Again," and "Prejudice Against Color." Douglass' later autobiographies (My Bondage and My Freedom and The Life and Times of Frederick Douglass), his break with William Lloyd Garrison, his support of John Brown, and the often militant and wide-ranging news- 
paper that he published for thirteen years are not represented in these anthologies.

The 1845 Narrative certainly establishes Douglass' authority and authenticity, and has been justly celebrated for its aesthetic beauty and its elucidation of such themes as freedom, literacy, and the horrors of slavery. But to have Douglass' canonization rest almost entirely on this text obscures the trajectory of Douglass' thought. The Narrative is a compelling account of one man's courage and a stinging moral indictment of the idea of slavery, but any institutional or economic critique must be inferred. A series of aspersions directed toward Christianity are the most overt criticism of any of the larger social systems that create and buttress slavery, and this criticism is carefully qualified and reduced to a condemnation of individual failures in the narrative's appendix. The fight with the slavemaster Covey that "rekindled" within Douglass "the few expiring embers of freedom and revived within me a sense of my own manhood" (Heath I679) stands, like the canonized Bigger Thomas' odyssey, as a celebration of individual spirit. The reader is left to make his or her own connections between Douglass' individual act of defiance and any larger group effort to repel "by force the bloody arm of slavery" (Heath I679).

But by the time Douglass delivers his "West India Emancipation" Speech in 1857 , the connection becomes explicit and directed more toward the direct resistance of oppression:

Those who profess to favor freedom yet deprecate agitation, are men who want crops without plowing up the ground; they want rain without thunder and lightning. They want the ocean without the awful roar of its many waters. . . Power concedes nothing without demand. It never did and it never will. Find out just what any people will quietly submit to and you have found out the exact measure of injustice and wrong which will be imposed upon them, and these will continue till they are resisted with either words or blow, or with both. The limits of tyrants are prescribed by the endurance of those whom they oppress. In the light of these ideas, Negroes will be hunted at the North, and held and flogged at the South so long as they submit to those devilish outrages and make no resistance, either moral or physical. Men may not get all they pay for in this 
world, but they must certainly pay for all they get. If we ever get free from the oppression and wrongs heaped upon us, we must pay for the removal. We must do this by labor, by suffering, by sacrificing, and if needs be, by our lives and the lives of others. (Foner 2:437)

This militancy is often accompanied by a broader and more systematic political and economic analysis than we see in the 1845 Narrative. In an $187 \mathrm{I}$ editorial Douglass begins to see slavery as one of the ways of satisfying Western capitalism's ongoing need for "Cheap Labor." Describing the international "Coolie" labor market as "kindred in character and results to the African slave trade of other days," he notes that "so rapidly does one evil succeed another, and so closely does the succeeding evil resemble the one destroyed, that only a very comprehensive view can afford a basis of faith in the possibility of reform" (Foner 4:264). This comprehensive view is reflected in an 1849 North Star editorial in which Douglass writes, "The welfare of the world demands the abrogation of monopolies" (Foner 5:106). This international and radical vision of reform is not represented in our canonized version of Douglass. Indeed, our anthologies tend to want to see Douglass in much the same way that many abolitionists wanted to use him-as a powerful witness to the experience of slavery, but not as a perceptive analyst of that experience.

The Souls of Black Folk (1903) is the text of choice for the canonization of W.E.B. Du Bois. The Heath anthologizes chapter I ("Of Our Spiritual Strivings"), chapter III ("Of Mr. Booker T. Washington and Others"), and chapter XIV ("Of the Sorrow Songs"). The Norton includes chapter III, and The Harper uses chapter III and chapter VII ("Of the Black Belt"). The McGraw-Hill anthology does not include Du Bois. Souls is certainly an extremely important book, but it is also a slender and very early contribution to one of the most distinguished and prolific careers in American letters. The selections available in our anthologies exclude sixty years of Du Bois' life and work: his on-again, off-again relationship with the NAACP, his work with The Crisis, his masterwork Black Reconstruction in America, and the enduring Marxism and PanAfricanism that made Du Bois an ongoing target of state harassment.

It is quite possible to argue that representing Du Bois with only The Souls of Black Folk is, in fact, a distortion of his contribution to Ameri- 
can culture. By the 1950s questions of class and wage differentials have become integral and inseparable parts of Du Bois' earlier, canonized notions of "the Talented Tenth" and "the problem of the Color Line." In a 1947 letter to Cecil Peterson, Du Bois laments that the Talented Tenth has produced "a large number of selfish and self-seeking persons, who will not work for the best interests of the masses of the people" (qtd. in Horne 224). The cultivation of an elite upper class of blacks exacerbates, rather than solves, racial problems. In the 1953 Monthly Review article "Negroes and the Crisis of Capitalism in the United States," Du Bois argues (with, as it turns out, a great deal of accuracy) that desegregation without accompanying economic reform would leave blacks "divided into classes even more sharply than now" (479). In a 1956 address in Prague, Du Bois sums up the evolution of his thinking:

[During the I930s] I repudiated the idea that Negroes were in danger of inner class division based on income and exploitation. Here again I was wrong. Twenty years later, by 1950, it was clear that the great machine of big business was sweeping not only the mass of white Americans ... it had also and quite naturally swept Negroes into the same maelstrom. (qtd. in Horne 224)

The recognition of this "great machine" leads Du Bois to complicate his famous pronouncement in the preface to The Souls of Black Folk that "the problem of the zoth century is the problem of the Color Line." By the r 950 s, as Gerald Horne points out, Du Bois is "edging toward the view that the twentieth century's problem was labor" (224). In a 1953 National Guardian article, he makes explicit his feeling that the problem of the color line can only be overcome with socialist reform:

There is but one aspect of this deepening world rift along the Color Line which saves it from being complete, and that is the peoples of the Soviet Union and her sister group of states.... For this fact, Britain, France, and the U.S. ought to be thankful to Russia for her refusal to be "white." (qtd. in Horne 224)

The link between "white" and capitalism which is crucial to the understanding of the bulk of Du Bois' career is not available to our survey students by reading only The Souls of Black Folk. 
This presentation of $\mathrm{Du}$ Bois is remarkable, but even more remarkable is the way that its inadequacy pales in comparison to the distortion of James Baldwin's career. "Sonny's Blues" is the lone Baldwin selection in all of our anthologies except The Norton, which prints an excerpt from The Fire Next Time. The headnotes in these anthologies all speak disparagingly or not at all about Baldwin's work after The Fire Next Time. This implicit evaluation is a lock-step reflection of the critical orthodoxy surrounding Baldwin: that the year following The Fire Next Time was, in the words of Baldwin biographer James Campbell, "the year his voice broke" ( 181 ), and that all of Baldwin's work after 1963 can be written off as "bitter" or "shrill."

This judgment, what Ekwueme Michael Thelwell calls "this simpleminded 'propaganda over art' . . . idiocy" that "has taken on the obduracy of sacred writ" (95), becomes somewhat curious when we consider that the dividing line between good Baldwin and bad Baldwin almost always comes after The Fire Next Time. Formally and stylistically, The Fire Next Time has more in common with No Name in the Street or The Evidence of Things Not Seen than it does with Baldwin's earlier work. In fact, perhaps the more persuasive argument is that Baldwin's style, especially his essay style-the autobiographical focus, the biblical cadences, the elliptical structures-changes very little throughout his career. The institutional concern over Baldwin's "broken voice" having "affected every element of his literary style-his rhythm, his syntax, his vocabulary ... away from the lyrical cadence that had been his signature tune" (Campbell I 8I) actually masks a fear directed more toward a changed political vision than a broken voice. The Fire Next Time has been deemed the last of Baldwin's "lyrical" and "graceful" works because it is the last of Baldwin's works to fall within acceptable canonical boundaries.

Baldwin's deep engagement with the Civil Rights and Black Power movements manifests itself in the series of texts that begins with The Fire Next Time and continues through Blues for Mr. Charlie, No Name In the Street, and The Devil Finds Work. The latter three books engage political and cultural America in terms of the Bible versus the gun, Martin versus Malcolm, the institutionalization of economic oppression, and the systematic reinforcement of racism in Hollywood film. The analysis is hard and clear-eyed, unwilling to accept the usual compromise explanations or integration solutions. The Fire Next Time, on the other hand, 
poses the familiar question of integration versus separatist Black nationalism, coming down on the acceptable side of integration. The end of the essay chronicles Baldwin's dinner with Nation of Islam leader Elijah Muhammad, and his ultimate rejection of the Nation's position in favor of the kind of utopian vision that made Baldwin the darling of the late I950s, early ig6os literary establishment:

If we-and now I mean the relatively conscious whites and the relatively conscious blacks, who must, like lovers, insist on, or create, the consciousness of the others-do not falter in our duty now, we may be able, handful that we are, to end the racial nightmare, and achieve our country, and change the history of the world. If we do not now dare everything, the fulfillment of that prophecy, recreated from the Bible in a song by a slave, is upon us: "God gave Noah the rainbow sign, No more water, the fire next time." (Price 379)

This is the sort of rhetoric that people from all points on the political compass can feel comfortable quoting in classrooms, campaign speeches, and Martin Luther King Day celebrations. By 1972, and the publication of No Name In the Street, Baldwin's vision has become much more historically and economically specific:

Huey believes, and I do, too, in the necessity of establishing a form of socialism in this country-what Bobby Seale would probably call a "Yankee Doodle type" socialism. This means an indigenous socialism, formed by, and responding to, the real needs of the American people. This is not a doctrinaire position, no matter how the Panthers may seem to glorify Mao or Che or Fanon. (It may perhaps be noted that these men have something to say to the century, after all, and may be read with profit, and are not, as public opinion would seem to have it, merely more subtle, or more dangerous, heroin peddlers.) The necessity for a form of socialism is based on the observation that the world's present economic arrangements doom most of the world to misery; that the way of life dictated by these arrangements is both sterile and immoral; and, finally, that there is no hope for peace in the world so long as these arrangements obtain. (Price 54I) 
The recognition of the need for economic change and the value of revolutionary thinkers, the fair-minded assessments of Muslims and Panthers, and not some aesthetic fall from grace, are the reasons why critics find Baldwin's later voice so bitter and discordant. The Marxist vision that played such a large role in the devaluation of the second half of Baldwin's career persists through the I970s and '8os, finding its fullest, most international expression in Baldwin's last book, The Evidence of Things Not Seen:

None of the "emerging" nations has arrived at economic autonomy, and this is not because they are incapable of selfgovernment, or are unable to count. One hears, for example, of the failure or the difficulty of their "export" market-which is not surprising, since this market is entirely controlled by the economic interests and arrangements of the West. On the "import" market, their situation is yet more precarious, since they can pay for these imports only in the Western currency that is being extracted from their flesh. A pound or a mark or a franc or a dollar or a diamond-or even, a barrel of oil-does not, in an African village, have the meaning it acquires on the stock exchange. (Just as my ancestors did not have, in their village, the meaning their descendants were to acquire on the stock exchange.) No one can eat or otherwise use or consume a franc or a mark or a pound or a dollar or a diamond (or a barrel of oil) except, perhaps, as a bribe: these must be invested, be placed in the situation in which they multiply, in which they re-create each other, a situation in which money makes money. $(28$, italics in original)

Baldwin had tremendous difficulty even finding an American publisher for The Evidence of Things Not Seen, and it remains today his most reviled work.

This reaction to third-world Marxism should prepare us for the erasure of the last sixteen years of Amiri Baraka's career. Baraka does not appear in The Harper American Literature and is represented by a handful of poems, none published after 1969 , in our other anthologies. This depiction of Baraka as nothing more than a sixties' relic ignores his downtown-uptown-hometown evolution from Beat fellow traveler to Black nationalist to third-world Marxist. The pattern here should be all 
too familiar by now. Baraka's early Williams-Pound-Olson-influenced integrationist verse and his late sixties cultural nationalism are represented, while his sixteen-year commitment to Marxist socialism is excluded. Our survey students have no access to the poetry from Hard Facts and Poetry for the Advanced, plays like What Was the Relationship of the Lone Ranger to the Means of Production, the essays on Aimé Césaire and Ngugi wa Thiongo in Daggers and Javelins, the eulogy for James Baldwin, the essays on Jesse Jackson, and the epic poem in-progress, Why's/Wise. Baraka himself recognizes what has been done to him in an early 1980 s essay:

Afro-American literature as it has come into view, fragmented by chauvinism and distorted by the same reactionary forces that have distorted American literature itself, has indeed been laid out in the same confusion and oblique fashion. A method intended to hide more than it reveals, a method that wants to show that at best Afro-American literature is a mediocre, and conservative, reflection of the mediocre and conservative portrait that is given of all American literature. (Harris 312)

This quotation is taken from an essay entitled "The Revolutionary Tradition in Afro-American Literature," and we must admit that the revolutionary impulses in the later work of Dougläss, Du Bois, Baldwin, and Baraka that we have examined here constitute a neglected tradition. The mature work of all of the writers in our survey tends toward trenchant social and economic critiques that question integrationist abolition and civil rights ideologies. Our canons do not acknowledge this tradition, instead representing each writer with relatively early works that celebrate ideologies of universalism and individual achievement, usually those that first brought these writers to the attention of the dominant white audience.

An argument could be made, of course, that these choices have been made on the basis of aesthetic, rather than political, criteria; that the choices for an anthology of literature must reflect literary merit rather than accurately reflect an author's career and thought, and thus the tradition we are examining here would be more suitable for an anthology of history or politics. Assuming for a moment that this distinction still matters to anyone, and ignoring the politics involved in separating lit- 
erary texts from other kinds, and also assuming that our authors' earlier works are in fact their most "literary," this argument is not one made by the anthologies we have examined here. All of the anthologies recognize that American "literature" is made up of texts that range well beyond the traditionally belletristic-including such forms as letters, journals, sermons, and political treatises-and The Heath's preface explicitly eschews a policy in which

texts concerned with . . . issues of religion and politics were mainly dismissed as outside the bounds of literary study. It seemed inconsistent to relegate Cabeza de Vaca, Frederick Douglass, or Charlotte Perkins Gilman to courses on history or politics. (xxxii)

This stance would also seem to suggest that it is "inconsistent" to exclude Black Reconstruction or No Name In the Street from an anthology that includes The Federalist Papers and Notes on the State of Virginia.

We should also point out that a scattering of texts from "the revolutionary tradition," like those from David Walker, Henry Highland Garnet, Sonia Sanchez, and Malcolm X have been included in some of the anthologies. But the way that Douglass, Du Bois, Baldwin, and Baraka have been anthologized falsely suggests that these writers stand more in the tradition that leads to Martin Luther King, Jr., than in the one that leads to Malcolm X. And the fact that Douglass, et al., are the writers most likely to appear in less inclusive anthologies or "Great Moments in Black History" television commercials creates a "major/minor" dichotomy that suggests that the revolutionary tradition is in no way central to the larger tradition of African American culture.

\section{V}

You will want cause and effect. All right.

Thomas Pynchon

The celebrated 1954 Supreme Court decision Brown vs. Board of Education was supposed to end segregation in American society in general and in our schools in particular. And despite its dismal failure to accomplish either of these things, ${ }^{7}$ the decision has been so canonized and imprinted on the national consciousness that the legal promise has 
become the rhetorical reality, to the point where many Americans are able to speak and write as though discrimination and segregation are perpetuated only in the minds of certain self-pitying black people (see, for example, Shelby Steele and Dinesh D'Souza). One of the things that perpetuates the misguided perception that the structure of American Apartheid has changed is the fact that Brown, and the various civil rights and Black Power movements that preceded and followed it, helped create the institutional space for Black Studies. But high-profile Black Studies programs often serve the same sort of masking purpose as the celebration of the Brown decision, overshadowing the continued de facto segregation of American universities. The classroom space that Brown earmarked for black bodies has been filled with black texts, while social justice remains just a promise.

As with the Brown decision, we like to think of the dissemination and canonization of these black texts as "progress" rather than as part of the perpetual deferral of justice. But even a cursory analysis of the segregation in our institutions or the material lives of a plurality of black people in this country suggests that this "progress" (and the canonization of African American literature as its symptom) is little more than a simulacrum for a reconstruction that never existed. What remains is to examine whether this situation is the result of a motivated abuse of power, what Mike Davis calls "coercive intent," or of an ineluctable social perpetual motion machine, what Frederic Jameson calls "cultural logic." Have cause and effect become so fragmented and disconnected as to leave us with only Jean Baudrillard's vision of complete seduction and shimmering surfaces? Have "us" and "them" become so indistinguishable as to leave us with nowhere to point the finger or even without a finger to point? In Baudrillard's America, the rhetoric of the $\mathrm{O}$. J. Simpson trial, the exclusion of Black revolutionary analysis, the Broum $v$. Board of Education decision, and the canonization of African American literature are all like Disneyland or Watergate-part of a funhouse internal "logic" where all opposition is only illusion produced "to regenerate a moral and political principle ... to regenerate a reality principle in distress" (Baudrillard 27).

This logic makes the polls that tell us how many black people believe O. J. Simpson to be always already innocent a "black thing," no matter what their roots in the racism of the American justice system. This "black thing" becomes part of the cultural nationalism that vali- 
dates the promise of integration (that validates all the "reasonable" people who must hear all the TV evidence before they can determine Simpson's guilt or innocence) through its demonized expression of opposition. This binary integration/nationalism logic excludes Baraka's "you must choose sides" stance as too binary, too simplistic, and out of touch. Thus Paul Lauter can appropriate a hologram of Stokely Carmichael to shill for a canonization process that avoids the binary "excesses" and "oversimplifications" of the Black revolutionary tradition in favor of a Supreme Court "pluralism" or "multiculturalism" where one need not choose sides.

But if we shift our terms from logic to power, choosing sides again becomes a possibility, and we can perhaps establish a foothold outside of the Baudrillardian totalizing and replicating system. If we see that system as an interlocking series of motivated institutions bent on protecting their side, then the systematic exclusion and silencing of the Black revolutionary tradition becomes an indication of the threat it poses to that side. The road from coINTELPRo to canon formation is certainly not a straight one, but we need not resort to bases and superstructures in order to recognize parallel and imbricated structures, what Jameson calls "homologies." The power behind the assassinations of Bunchy Carter, Fred Hampton, and Malcolm X may have mellowed to logic by the time we reach the cultural field of curriculum, but we must never forget that it is a logic that derives from the deadly use of that power.

Western Washington University

\section{NOTES}

1. Just as the black people most comfortably integrated into such institutions as schools, businesses, and Supreme Courts are those who best reflect the cultural expectations already in place, the Black texts that move most easily from Baumbach's Negro ghetto to the more luxurious Universal neighborhood are those who seem to resemble the Joyces and Faulkners who have always lived there. As we have opened the canon to black voices we have tried to look beyond blackness and toward some kind of "objective" literary merit. Critics and reviewers make African-American literature safe for the canon by telling us that race has nothing to do with it. William Stanley Braithwaite, for example, in a discussion of Cane, is careful to show race transcended when he describes Jean Toomer as "the very first artist of the race, who ... can write about the Negro without the surrender or compromise of the author's vision" (qtd. in Turner ix). The Washington Post, in a review of Sent For You 
Yesterday, gives John Edgar Wideman an artistic pedigree-by-comparison by telling us that "like Faulkner's, Wideman's prose fiction is vivid and demanding." And The Houston Chronicle makes sure that standards are maintained by bestowing on Toni Morrison's The Bluest Eye "a sense of timelessness that is the mark of great literature." It comes as no surprise that these reviews are the ones that the publishers chose for cover blurbs.

2. Speech given at the University of Puget Sound, February 22, 1995.

3. This Professoriat has come to be canonized in the popular media the same way that African American literature has been canonized in academia. West, Gates, and Dyson all acknowledge their debts to various kinds of nationalism. But the television and magazine portrayals of these thinkers all tell us to see them as more "reasonable" than their predecessors.

4. For a history of FBI operations directed against the Black Panther Party, see Churchill and Vander Wall, and Blackstock. For a discussion of the transformation of young Black male resistance energy from politics to "the political economy of crack," see Davis, 293-3i6.

5. See Evanzz.

6. See Garrow.

7. See Rosenberg.

\section{WORKS CITED}

Baker, Houston A., Jr. Blues, Ideology, and Afro-American Literature: A Vernacular Theory. Chicago: University of Chicago Press, 1984.

Baldwin, James. The Evidence of Things Not Seen. New York: Holt, Rinehart, and Winston, 1985 .

. The Price of the Ticket: Collected Nonfiction 1948-1985. New York: St. Martin's Marek, 1985. 449-552.

Baraka, Amiri. "The Revolutionary Tradition in Afro-American Literature." The LeRoi Jones/Amiri Baraka Reader. Ed. William J. Harris. New York: Thunder's Mouth Press, 1991 .

Baudrillard, Jean. Simulations. New York: Semiotext(e), Inc., 1983.

Baumbach, Jonathan. The Landscape of Nightmare. New York: New York University Press, 1965.

Baym, Nina, et al., eds. The Norton Anthology of American Literature, vols. I and 2. $4^{\text {th }}$ edition. New York: Norton, 1994.

Blackstock, Nelson. COINTELPRO: The FBI's Secret War on Political Freedom. New York: Vintage Books, 1976.

Bloom, Harold. "Introduction." Richard Wright's Native Son. Ed. Harold Bloom. New York: Chelsea House, I 988.

Bone, Robert. Richard Wright. Minneapolis: University of Minnesota Press, i 969. Boynton, Robert S. "The New Intellectuals." The Atlantic Monthly 275.3 (March I995): 53-70.

Campbell, James. Talking At the Gates: A Life of James Baldwin. New York: Viking, I99I. 
Carby, Hazel. "The Multicultural Wars." Black Popular Culture. Ed. Gina Dent. Seattle: Bay Press, I992. 187-99.

Carmichael, Stokely, and Charles V. Hamilton. Black Power: The Politics of Liberation in America. New York: Vintage Books, 1967.

Cheyfitz, Eric. "The lrresistibleness of Great Literature: Reconstructing Hawthorne's Politics." American Literary History 6.3 (Fall 1994): 539-58.

Churchill, Ward, and Jim Vander Wall. Agents of Repression: The FBI's Secret Wars Against the Black Panther Party and the American Indian Movement. Boston: South End Press, 1990.

Davis, Mike. City of Quartz: Excavating the Future in Los Angeles. New York: Vintage Books, 1992.

Douglass, Frederick. "Cheap Labor." The Life and Writings of Frederick Douglass, 5 vols. Ed. Philip S. Foner. New York: International Publishers, 1950, I971; 4:264-66.

- "West India Emancipation." In Foner. 2:437.

Du Bois, W.E.B. "Negroes and the Crisis of Capitalism in the United States." Monthly Review 4 (April 1953): 478-85.

Ellison, Ralph. Shadow and Act. New York: Random House, 1964.

Evanzz, Karl. The Judas Factor: The Plot to Kill Malcolm X. New York: Thunder's Mouth Press, I992.

Garrow, David J. The FBI and Martin Luther King, Jr.: From Solo to Memphis. New York: Norton, I $98 \mathrm{I}$.

Hemingway, Ernest. Green Hills of Africa. 1935. New York: Scribners, 1987.

Horne, Gerald. Black and Red: W.E.B. Du Bois and the Afro-American Response to the Cold War, 1944-63. Albany: State University of New York Press, 1986.

Howe, Irving. "Black Boys and Native Sons." A World More Attractive. New York: Horizon, 1963 .

Karenga, Ron. "Black Cultural Nationalism." The Black Aesthetic. Ed. Addison Gayle, Jr. New York: Doubleday, 1971.

Lauter, Paul. Canons and Contexts. New York: Oxford University Press, 1994.

- ed. The Heath Anthology of American Literature, vols. I and 2. 2nd edition. Lexington, Mass.: D. C. Heath, 1990.

McCall, Dan. The Example of Richard Wright. New York: Harcourt, 1969.

McCall, Nathan. Makes Me Wanna Holler. New York: Random House, 1994.

McQuade, Donald, ed. The Harper American Literature, vols I and 2. 2nd edition. New York: Harper Collins, 1994.

Nelson, Jill. "Hiding in Plain Sight." The Nation 258.16 (April I9, 1994): 562-65.

Perkins, George, and Barbara Perkins. The American Tradition in Literature. 8th edition. New York: McGraw-Hill, 1994.

Rosenberg, Gerald N. The Hollow Hope: Can Courts Bring About Social Change? Chicago: University of Chicago Press, 1991.

Siegel, Paul N. "The Conclusion of Richard Wright's Native Son." Richard Wright: A Collection of Critical Essays. Ed. Richard Macksey and Frank E. Moorer. Englewood Cliffs, N.J.: Prentice Hall, 1984. 
Tiger Teeth Around Their Neck

125

Smith, David Lionel. "The Black Arts Movement and Its Critics." American Literany History 3.1 (Spring 1991): 93-1 I0.

Thelwell, Ekwueme Michael. "A Prophet is Not Without Honor." Transition 58: 90-II3.

Turner, Darwin T. "Introduction." Cane. By Jean Toomer. New York: Norton, 1975. ix -xxv.

Williams, Patricia J. The Alchemy of Race and Rights: Diary of a Law Professor. Cambridge: Harvard University Press, 1991.

Wright, Richard. "How Bigger Was Born." Native Son. New York: Harper, 1940, vii-xxxiv.

Native Son. New York: Harper, 1940.

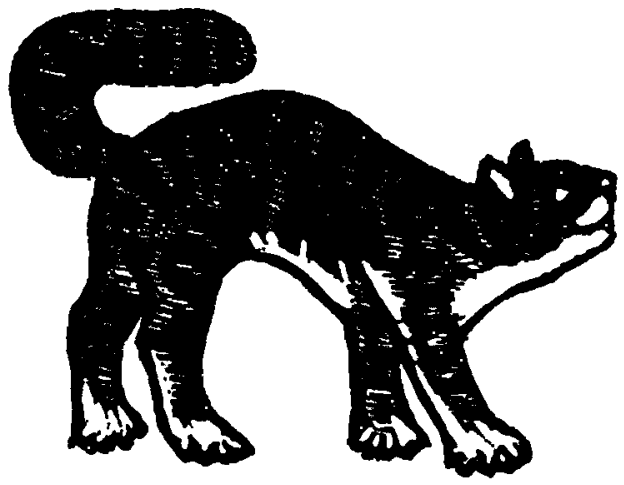

